J. Brew. Soc. Japan, Vol. 79, No.8, p. 581 582 (1984)

\title{
酵素剤仕込での高濃度アルコール生成に 及济す精白米の影響
}

\author{
中里厚実・保阪良雄* - 竹田正久 - 塚原寅次* \\ (東京農業大学短期大学醕造科・* 東京農業大学農学部锼造学科) \\ 昭和 59 年 2 月 15 日受理
}

\begin{abstract}
Influence of Polished Rice on Production of High Concentration of Alcohol in the Mash with Enzymatic Preparations

Examination of Production of High Concentration of Alchol in the Mash with Enzymatic Preparations (Part 1)
\end{abstract}

Atumi Nakazato, Yoshio Hosaka, Masahisa Takeda, and Toraji Tsukahara

(Department of Brewing and Fermentation, Junior College of Tokyo

University of Agriculture, 1-1-1 Sakuragaoka, Setagaya-ku, Tokyo, 156)

\section{緒言}

清酒もろみで间濃度 (20\%以上)のアルコールを生成 するのは清酒酵母群, 焼酎酵母群, 泡盛酵母群で Sacharomyces cerevisiaeに属するビール酵母，パン酵母，ぶ ぞら酒酵母, アルコール酵母, 樹液酵母等の酵母群は生 成 $(20 \%$ 以下) しないことを，また米麴を全く用いない 酵素剂仕込でも清酒酵母群が高濃度のアルコールを生成 することを報告1した。米粎には高濃度アルコール生成 を促進するプロテオリピドが存在するが，米䊝を全く使 用しない酵素郕仕込でも高濃度のアルンールが生成され たことは、プロテオリピドと同効果を示す米プロティン ボディの効果によるものと推察1した。林田22らは，75\% 精白米のプロティンボディ含量は米棅の 36 分の 1 程度 であり実地醸造では米楼中のプロテオリピドが高濃度ア ルュール生成に関与していると推察している。

前報 ${ }^{1}$ で用いた白米は 90〜92\% 精米歩合であったの で，本報では 90\%，70\%，60\%の精白米を用いて，酵素 剂仕込での高濃度アルコール生成の比較試験を行った。

\section{実 験 方 法}

使用菌株 清酒酵母の協会 7 号

酵素剂仕込も万み(培養基) 仕込配合を第 1 表に示 す。米㷊を全く用いない酵素剂仕込で, $500 \mathrm{ml}$ 容三角〉 ラスコを用い, 綿栓を施して行ったが同一のものを7〜

酵素剂仕込での高濃度アルコール生成試騒（第 1 㪕）
8 本仕込み, 分析の時はその 1 本について行った。酵素 剂は $\mathrm{a}, \mathrm{b} の 2$ 種類を併用したが, a Bacillus 起源で 力価は, $\alpha$-amylase 1005 units/mg, glucoamylase 57 units/mg, acid protease $0 / \mathrm{mg}_{\circ}$ bはRhizopus 起源で 力価は, $\alpha$-amylase 75 units/mg, glucoamylase 125 units/mg, acid protease 2, 200 units/mg であった。尚, $\alpha$-amylase $\varepsilon$ acid protease 活性は国税庁所定分析 法3)で测定し, 活性単位はそれぞれ $U=D_{30^{\prime}}^{40^{\circ}}, \mathrm{U}=$ $r$ tyrosin/60' で, glucoamylase は岩野 ${ }^{4)}$ の力法で测定 し, 活性単位は $\mathrm{U}=\mathrm{mg}$ glucose $/ 60^{\prime}$ で表わした。また酵 素剂は $70 \%$ アルコールで 3 回洗浄して用いた。酵母は YM（グルコース $1 \%$ ， ペプトン $0.5 \%$ ，酵母エキス $0.3 \%$ ，マルトエキス $0.3 \%$ ）液体培地に $30^{\circ} \mathrm{C} ， 4$ 日間 培養した菌体を生理食塩水で 3 回洗浄して, 初添仕込で (1.5 3.0) $\times 10^{7}$ の菌体量を添加した。初添仕込後は $(1.5 \sim 3.0) \times 10^{5} / \mathrm{m} l$ の接種濃度となる。また, 初添仕込

第 1 表 酵素剤仕込もろみの配合

\begin{tabular}{|c|c|c|c|c|}
\hline & 初 & 伸 添 & 留 添 & 総 計 \\
\hline 雚米 $(\mathrm{g})$ & 40 & 50 & 70 & 160 \\
\hline 汲水 $(\mathrm{m} l)$ & 100 & 74 & 10 & 184 \\
\hline 乳酸 $(75 \%)(\mathrm{ml})$ & 0.2 & & & \\
\hline 酐母菌体 & $(1.5 \sim 3.0) \times 10^{7}$ & & & \\
\hline 醉菜剂 $\left\{\begin{array}{l}a(g) \\
b(g)\end{array}\right.$ & $\begin{array}{c}0.012 \\
0.020 \\
\text { 栄筫源洒加* }\end{array}$ & $\begin{array}{l}0.015 \\
0.025\end{array}$ & $\begin{array}{l}0.021 \\
0.035\end{array}$ & $\begin{array}{l}0.080 \\
0.080\end{array}$ \\
\hline
\end{tabular}

* 栄韵源添加: $\left(\mathrm{NH}_{2}\right)_{2} \mathrm{CO} 0.4 \mathrm{~g}, \mathrm{NaH}_{2} \mathrm{PO}_{4} \cdot 2 \mathrm{H}_{2} \mathrm{O} 0.46 \mathrm{~g}, \mathrm{KCl} 0.22$ $\mathrm{g}, \mathrm{MgSO}_{4} \cdot 7 \mathrm{H}_{2} \mathrm{O} 0.08 \mathrm{~g}$, inositol $5,000 \mathrm{r}$, Pantothenate $500 r$, biotin $2 r, \mathrm{~B}_{1} 500 r, \mathrm{~B}_{6} 200 \gamma$, niacin $200 r$. 
で尿素, リン酸 1 ナトリウム, 塩化カリウム, 硫酸マグ ネシウム及びビタミン B 群の 6 種類を添加した。

初添は 27〜 $28^{\circ} \mathrm{C}$ で 3 日間, 仲添は 18〜 $22^{\circ} \mathrm{C} て ゙ 2$ 日間, 留添は $18 \sim 22^{\circ} \mathrm{C}$ で行い, 発酵終了まで同温で行った。

生菌数 YM 寒天 $(3 \%)$ 培地を溶解し, アルコール （約 $4 \%$ ) を加えてシャーレに分注し固化後，その表面 に 100 個前後のコロニーが出現するように適宜希釈し た試料 $0.05 \mathrm{ml}$ を叙抹した。 $30^{\circ} \mathrm{C}, 3 \sim 4$ 日間培養し出 現したコロニーから計算して, $\mathrm{m} l$ 中の酵母の生菌数と して表示した。

アルコール分の測定 ろ液を蒸留して浮ひよら法で 湘定し，容量\%で示した。

\section{実 験 結 果}

結果を第 1 図に示す。生菌数は仲添（前）で 60\% 精 白米使用もろみが高い数を示したが，留添（前）と 4 日 目の生菌数は $90 \%$ 精白米使用の 方が多く，4 日目が $90 \%$ 精白米使用もろみ $2.0 \times 1.0^{8} / \mathrm{ml}, 70 \%$ 精白米もろ み $1.0 \times 10^{8} / \mathrm{ml}, 60 \%$ 精白米もろみ $8.0 \times 10^{7} / \mathrm{ml}$ であっ た。その後の生菌数は減少を始めるがアルコール濃度と の関係が深い。アルコール生成量は $90 \%$ 精白米使用の 方が常に高く, 最高の生成量も多く, そして最高生産量 に達する日数も早い。90\% 精白米もろみが 11 日目の $21.7 \% ， 70 \%$ 精白米もろみが 19 日目の $20.6 \% ， 60 \%$ 精白米もろみが 23 日目で $20.0 \%$ を示すように, 最高 のアルコール生産量に差はあったが，いずれのもろみで も高濃度のアルコール生成が可能であった。 $90 \%$ 精白米もろみが 8 日目のアルコール $19.7 \%$,

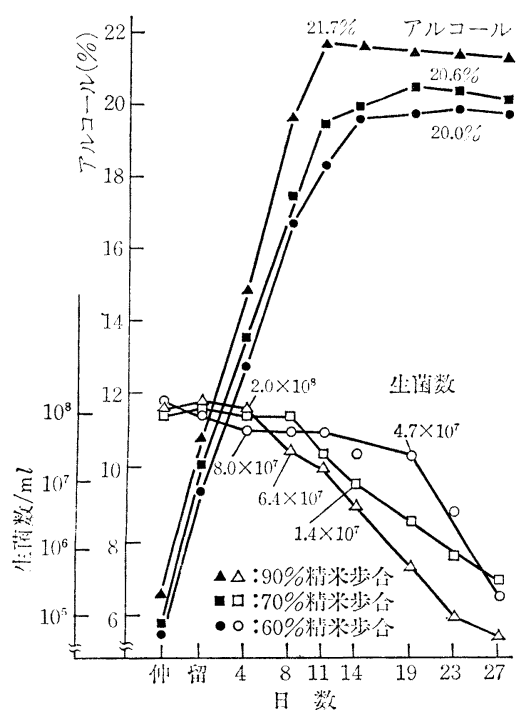

第1図アルュール生成と生菌数の消 長に及ぼす精白度の影響
生菌数 6.4 $\times 10^{7} / \mathrm{m} l の$ 状態から11 日目のアル コール 21.7 \%までに疃 加し，70\% 精白米もろ 又が 14 日 目のアルコ 一ル20.0\%. 生菌数 1.4 $\times 10^{7} / \mathrm{ml}$ か 519日目の アルコール $20.6 \%$ をて 増加，また $60 \%$ 精白米
もろみが 19 日目のアルュール $19.8 \%$, 生菌数 $4.7 \times 10^{7}$ $\mathrm{ml}$ から 23 日目のアルコール $20.0 \%$ までに增加した。

\section{考察}

精米操作で酵母の栄荃となる窒素源, ミネラル，ビタ ミン B 群が減少5することは周知の通りで方る。それを 補らために尿素, リン酸 1 ナトリウム, 塩化カリウム, 硫 酸マグネシウム及びビタミン B 群を初添で添加したにも かかわらず，初期の生菌数及びアルニール生成量と，そ の生成速度は粗白米使用の方が優り，また $90 \%$ 精白米 もらみが $21.7 \%$ のアルコールを生成したのに比べ，70 $\%$ と $60 \%$ 精白米もろみが $21.7 \%$ のアルニール生産量 に達しない前に生菌数が $10^{7} / \mathrm{ml}$ のオーダを維持するこ とができなかったことなどから，初添時に添加した栄養 源の外に白米中に含季的物質が酵母の増殖能，高濃度 アルコール生成能, 生存能のアルコール耐性に関係して いることが考えられる。三つのもろみとも高濃度のアル コールが生産されたとは言え精白度の違いで差異が生じ たことは，これらの物質の含有量に違いが生じているも のと思われる。しかし，本実験結果からも解るように， 高精白米を用いたとしても高濃度アルニール生成に米釈 の使用が必要条件とはならない。

要 約

米䔩を全く用いない酵素剂仕込で，高濃度（20\%以 上）フルコール生成に及ぼす精白米の影響を娭討した。 最高のアルコール生産量は，90\% 精白米使用もろみ が $21.7 \%$ ，70\% 精白米使用が $20.6 \% ， 60 \%$ 精白米使

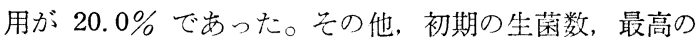
アルコール濃度に達するまでの速度, 生存能のアルコー ル耐性も粗精白米使用の方が秀れていたここのように差 が生じたことは，白米中には添加した栄養源の外に高濃 度のアルコール生成を促進する物質が存在し, 精白度の 違いによってこれらの物質の含有量に差異があると推察 した。しかし，60\% 精白米使用もろみでも20\% 濃度の アルコールが生成されたこと坊，高濃度アルコール生 成に米麥迷の使用が必冴条件とはならない。

\section{文献}

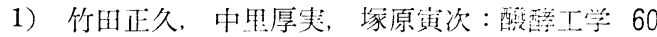
137(1982)

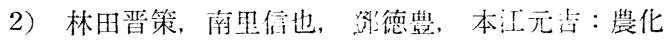
48529 (1974)

3）国税庁所定分析法 日本醉造協会 (1974)

4）岩野君夫, 風間敬夫, 布川弥太郎：酷搷 71(5) 383(1976)

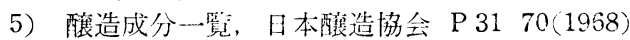

